\begin{tabular}{|l|l|l||}
\hline \multicolumn{2}{|c|}{ PublisherInfo } \\
\hline \hline PublisherName & $:$ & BioMed Central \\
\hline \hline PublisherLocation & $:$ & London \\
\hline \hline PublisherImprintName & $:$ & BioMed Central \\
\hline \hline
\end{tabular}

\title{
Limited variation
}

\begin{tabular}{|l|l|l||}
\hline \multicolumn{2}{|c|}{ ArticleInfo } \\
\hline \hline ArticleID & $:$ & 4261 \\
\hline \hline ArticleDOI & $:$ & $10.1186 /$ gb-spotlight-20011126-01 \\
\hline \hline ArticleCitationID & $:$ & spotlight-20011126-01 \\
\hline \hline ArticleSequenceNumber & $:$ & 332 \\
\hline \hline ArticleCategory & $:$ & Research news \\
\hline \hline ArticleFirstPage & $:$ & 1 \\
\hline \hline ArticleLastPage & $:$ & 2 \\
\hline \hline & & RegistrationDate : 2001-11-26 \\
ArticleHistory & $:$ & OnlineDate $\quad$ 2001-11-26 \\
\hline \hline ArticleCopyright & $:$ & BioMed Central Ltd2001 \\
\hline \hline ArticleGrants & $:$ & \\
\hline \hline ArticleContext & $:$ & 130592211 \\
\hline \hline
\end{tabular}




\section{Jonathan B Weitzman}

Email: jonathanweitzman@hotmail.com

Small differences in DNA sequence are thought to account for the wide variation between people. In the November 23 Science, Nila Patil and researchers at Perlegen Sciences Inc. in California, suggest that the differences might be less than we had thought (Science 2001, 294:1719-1723). They set out to map a large number of common single nucleotide polymorphisms (SNPs) on human chromosome 21 and to define their haplotype structure. They took a panel of 24 individuals and used a rodent-human somatic cell hybrid technique to separate each person's two copies of chromosome 21. Patil et al. constructed high-density oligonucleotide arrays corresponding to $21.6 \mathrm{Mb}$ of non-repetitive sequence from chromosome 21 (3.4 x 109 oligonucleotides) and screened 20 independent copies of chromosome 21. They did this by generating 3253 long-range PCR products for each sample; in this way they could map almost 36,000 SNPs. They found that the SNPs occurred in blocks (on average $7.8 \mathrm{~Kb}$ long) along the chromosome. Surprisingly, just three common haplotypes characterize variations among $80 \%$ of the human population. It appears that at the haplotype level we are perhaps more alike than we look.

\section{References}

1. Variation is the spice of life.

2. Science, [http://www.sciencemag.org]

3. Perlegen Sciences Inc, [http://www.perlegen.com]

4. Experimentally-derived haplotypes substantially increase the efficiency of linkage disequilibrium studies. 